\title{
Geometric Accuracy Study of Orthorectification Based on Sensor Model Refinement in Imagery Subset Using ORFEO Toolbox (OTB)
}

\author{
Andri Suprayogi ${ }^{1}$, Nurhadi Bashit ${ }^{2}$, \\ ${ }^{1}$ Cadastral Survey And Mapping Coordinator, Geodetic Engineering Dept. Engineering Faculty OF UNDIP, Indonesia \\ 2 Lecturer Of Geodetic Engineering Dept., Engineering Faculty OF UNDIP, Indonesia
}

\author{
Article History: \\ Received 29 November 2018 \\ Received in revised form 1 June 2019 \\ Accepted 11 June 2019 \\ Available online 28 June 2019
}

\section{Keywords: \\ Accuracy, Sensor Model, OTB, Big Data, pan sharpening}

\section{Corresponding Author:}

Andri Suprayogi

Email : andri.suprayogi@ft.undip.ac.id

\begin{abstract}
Large scale base map can be obtained by various methods, one of them is orthorectification process of high resolution satellite imagery with relatively large file size to eliminate the relief displacement caused by height variation of earth surface. It requires additional data such as sensor model in the form of rational polynomial coefficients (RPC), surface model data, and ground control points. In order to process a large file size, high specification of hardwares were required. To overcome this, several remote sensing software such as ESA SNAP and Orfeo Toolbox (OTB) able to subset or extract a portion of satellite imagery, preserve the imagery geometric sensor models.

This research aimed at geometric accuracy of orthorectification carried out in a single scene of Pleiades Imagery within the Kepahiang Subdistrict, located at Kepahiang Regency, Bengkulu Province, by using DEMNAS and the imagery refined sensor mode, and ground control points taken using GPS Survey The orthorectification carried out both in full extent imagery and the subset imagery. After these processses taken place, we measure the accuracy of each full and subset imagery. These procedures were carried out using Orfeo toolbox 6.6.0 in the Linux Mint 19 Operating system. A performance measurement also carried out, contributing to the review of OTB as an open source program.

From the process logs, processing time for the full image were 7814.518 seconds and for the subset were 4321.95 seconds. And as a big data process, the total of full extent size was 83.15 GB while the subset size was only 30.73 GB. Both the time and size shows that subset were more economical. The relative accuracy of the full extent and its subset imagery were 0.431 meters. Accuracy of the sensor model refinement process are 1.217 meters and 1.550 meters with GCP added, while the accuracy of the orthorectifications results were 0.416 meters and 0.751 meters by using ICP. Variation of execution time may caused by the data input size and complexity of the mathematical process carried out in each stages.Tthe variation of accuracy may caused by the check or control points placements above satellite Imagery which suffer from uncertainty when dealing with the sub-pixel position or under 0.5 meters.
\end{abstract}

(C) Author(s) 2019. This is an open access article under the Creative Commons Attribution-ShareAlike 4.0 International License (CC BY-SA 4.0).

\section{Pendahuluan}

Peta dasar berskala besar dapat diperoleh diantaranya dengan proses ortorektifikasi citra satelit penginderaan jauh untuk mengeliminasi kondisi pergeseran relief pada citra satelit akibat

adanya variasi tinggi permukaan bumi. Dibutuhkan data tambahan berupa data sensor model yang dapat berupa model rational polynomial coefficients (RPC), data model permukaan, serta data titik kontrol tanah untuk menghasilkan peta citra dengan kualitas geometrik yang baik sebelum dapat digunakan untuk keperluan lebih lanjut (Mateo C. M. R., dkk., 2017).

Ortorektifikasi adalah salah satu metoda untuk memperbaiki kondisi geometrik akibat kesalahan pergeseran relief. Terdapat dua jenis ortorektifikasi dimana yang pertama disebut dengan ortorektifikasi 
sistematik yang tidak menggunakan titik kontrol tanah (GCP), dalam mengoreksi satelit (Widyaningrum, dkk., 2016). dan yang kedua dengan memperhitungkan koordinat titik GCP diantaranya dalam bentuk sensor model refinement (OTB Development Team ${ }^{1}$, 2018). Dalam beragam aplikasi seperti PCI Geomatica, ENVI, dan paket ERDAS Imagine, akurasi hasil yang diharapkan ditampilkan pada tahap penempatan GCP, yang memandu operator untuk menentukan baik tidaknya penempatan titik-titik tersebut. (Hoja, dkk., 2008).

Citra satelit dengan resolusi tinggi memiliki ukuran yang besar sehingga pengolahannya membutuhkan peralatan dengan spesifikasi yang tinggi. Pemotongan citra secara langsung berdasarkan area tertentu memiliki resiko hilangnya georeferensi dari suatu citra, sehingga tidak dapat diortorektifikasi. Beberapa perangkat lunak pengolahan citra penginderaan jauh diantaranya Orfeo Toolbox (OTB) dikenal istilah subset yang merupakan hasil ekstraksi terhadap sebagian citra namun georeferensi dan model sensor dari citra tersebut tetap dipertahankan (OTB Development Team ${ }^{1}$, 2018).

Penelitian ini bertujuan untuk mengkaji ketelitian geometrik dari proses sensor model refinement terhadap subset citra Pleaides sebelum ortorektifikasi dilakukan (Muller, dkk., 2011). Perbaikan sensor tersebut menggunakan data titik kontrol tanah hasil pengamatan GPS yang telah dilakukan sebelumnya.

Sasaran yang dicapai dalam penelitian ini berkaitan dengan performa sistem pada saat pengolahan dengan kondisi citra masukan yang terdiri dari band pankromatik dan multispektral. Setelah tahapan assembly, dilakukan proses subset citra, kemudian koreksi radiometrik dan fusi citra. Sensor Model Refinement pada citra utuh maupun pada subsetnya dilakukan sebelum ortorektifikasi yang akan dianalisis ketelitiannya.

\section{Data dan Metodologi}

Pada penelitian ini aspek penting untuk mencapai tujuan dan sararan penelitian, diantaranya peralatan yang digunakan, data, lokasi, dan metodologi penelitian sebagai berikut :

\subsection{Data dan Lokasi}

Dalam penelitian ini, data primer maupun data pendukung yang akan digunakan diantaranya adalah sebagai berikut :

a. Citra Pleiades 1B Pankromatik resolusi 0.5 meter dan Multispektral resolusi 2 meter tahun perekaman 2014 (sumber : Lapan)

b. DEMNAS sebagai data DEM Utama yang bereferensi ke geoid EGM 2008 (Sumber : BIG)

c. Koordinat Titik GPS hasil survey lapangan yang digunakan sebagai GCP dan ICP berikut formulir lapangan untuk Orientasi Penempatan Titik

d. Tinggi Geoid EGM 2008
Penelitian ini dilakukan pada area studi kecamatan Kepahiang, Kabupaten Kepahiang, Provinsi Bengkulu. Kecamatan Kepahiang merupakan merupakan ibukota Kabupaten Kepahiang dengan luas 7.192 hektar Pada ketinggian rata-rata 452 meter diatas permukaan laut (BPS Kab. Kepahiang, 2017). Kecamatan Kepahiang terbagi menjadi 23 wilayah administrasi yang sebagian besarnya dalah desa dan hanya 7 diantaranya yang berstatus kelurahan. Wilayah administrasi dengan jarak paling dekat dengan ibukota kecamatan adalah Pasar Ujung sedangkan desa/kelurahan yang berjarak paling jauh adalah kelurahan pagar Gunung. (BPS Kabupaten Kepahiang, 2017). Secara Administratif, kecamatan Sangir berbatasan dengan :

Tabel 2.1. Batas Administrasi Kecamatan Kepahiang

\begin{tabular}{ll}
\hline Arah & Perbatasan \\
\hline Utara & Kec. Kabawetan, Kec. Utan Mas \\
Timur & Kec. Tebai Karai \\
Barat & Kec. Seberang Musi \\
Selatan & Kec. Bengkulu Tengah \\
\hline Sumber : BPS Kab. Kepahiang, 2017
\end{tabular}

\subsection{Peralatan Penelitian}

Penelitian ini dilakukan pada sistem open source yang dengan aplikasi-aplikasi yang mendukung proses ortorektifikasi data citra satelit resolusi tinggi baik itu citra ali maupun citra hasil subset sebagai berikut :
a. Sistem Operasi Linux Mint 19 Cinnamon Edition
b. Orfeo ToolBox 6.6.0
c. Quantum GIS 3.2.1
d. ESA SNAP Toolbox 6
e. Libreoffice Calc 5

Perangkat yang digunakan dalam penelitian ini memiliki spesifikasi sebagai berikut yaitu :
a. $\quad$ CPU i7-3770 3,4 Ghz, 4 cores 8 Thread
b. Memory DDR3 PC $133316 \mathrm{~GB}$
c. 1 TB HDD WD10EZEX-00BN5A00 64 MB Cache
d. Display Unit Viewsonic 19 Inch

\subsection{Metodologi}

Pada awal penelitian ini, dilakukan proses ekstraksi subset citra berdasarkan region of interest (ROI) citra utuh dengan luaran subset yang berukuran lebih kecil. Terhadap data citra utuh dan citra subset, dilakukan tahapan-tahapan sebagai berikut :
a. Assembly data (sebelum ekstraksi data)
b. Kalibrasi Optik dan Fusi Citra
c. Penempatan GCP
d. Sensor Model Refinement dan Ortorektifikasi (Sistematik) sebagai bagian dari proses ortorektifikasi yang memanfaatkan data GCP

Dalam ortorektifikasi, diperlukan ketinggian yang mengacu pada referensi yang sama. Data DEMNAS yang 
masih bereferensi terhadap MSL dikoreksi dengan data tinggi Geoid EGM 2008 (Gambar 2.1.a) Tinggi geoid yang dimaksud adalah selisih tinggi antara ellipsoid dan geoid atau undulasi yang ditunjukkan pada Gambar 1. DEM yang bereferensi seragam terhadap ellipsoid WGS 1984 diperoleh dengan perhitungan sebagaimana ditunjukkan pada persamaan 1

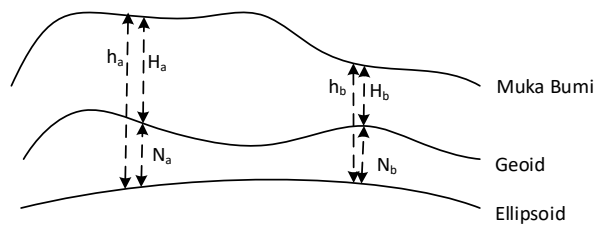

Gambar 1. Ilustrasi Tinggi Geoid dan Tinggi Ellipsoid

Keterangan :

$$
\mathrm{h}=\mathrm{H}+\mathrm{N}
$$

$\mathrm{H}=$ Tinggi Geoid

$\mathrm{N}=$ Undulasi

$\mathrm{h}=$ Tinggi Ellipsoid

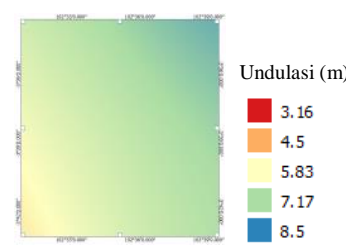

(a)

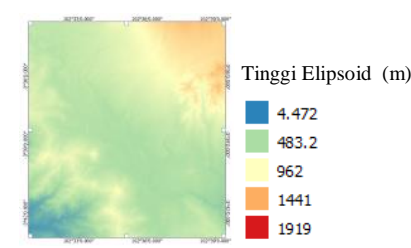

(b)
Gambar 2.1. Dalam (a) Nilai Undulasi dan (b) Tinggi Elipsoid

Proses pemotongan dan kalkulasi raster DEM untuk menghasilkan data DEMNAS bereferensi elipsoid dilakukan dengan aplikasi QGIS dengan keluaran berformat tif sebagaimana ditunjukkan pada Gambar 2.1.b.

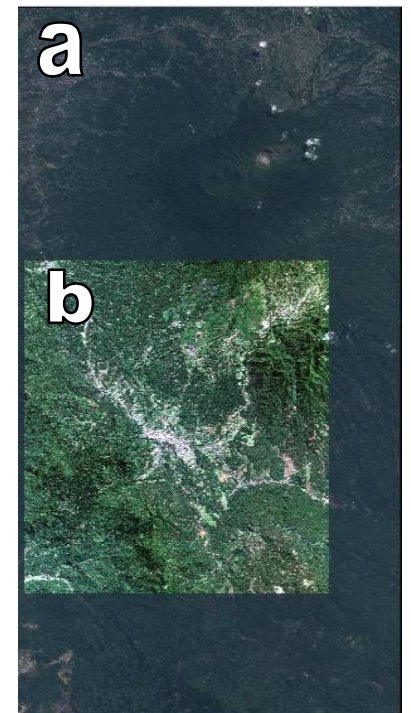

Gambar 2.2. Hasil Assembly Band MS Citra Pleiades (a) dan subsetnya (b)
Tahapan awal dari proses pengolahan citra dalam penelitian ini adalah tahap assembly atau penggabungan tile baik itu band multispektral (MS) maupun band pankromatik (P). Citra mentah yang masih terpotong dalam struktur format DIMAP (.DIM) digabung menjadi format tif dengan header berformat Open Source Software Image Map atau OSSIM (OTB Development Team, 2018). Pada Gambar 2.2.(a), nampak citra utuh sebagai hasil dari proses assembly band MS.

Citra yang telah digabungkan kemudian diekstraksi untuk mendapatkan subsetnya. Pada penelitian ini, digunakan nilai Region of interest (ROI) dengan batasbatas koordinat dengan sistem proyeksi UTM Zona 48S sebagaimana ditunjukkan pada Tabel 2.2. Dari ekstraksi tersebut diperoleh citra pleiades dengan luas area yang lebih kecil sebagaimana ditunjukkan dalam bagian terang dari citra Pleiades pada pada Gambar 2.2.(b)

Tabel 2.2. Region of Interest Subset Citra

\begin{tabular}{lcc}
\hline \multirow{2}{*}{ Cakupan } & \multicolumn{2}{c}{ Koordinat (m) } \\
\cline { 2 - 3 } & $\mathbf{X}$ & Y \\
\hline Kiri Atas & 223725,981 & 9606184,699 \\
Kanan Bawah & 239749,679 & 9588652,024 \\
\hline
\end{tabular}

Proses kalibrasi optik dilakukan untuk memperbaiki kondisi radiometrik dengan pendekatan koreksi Top of Atmosphere (TOA). Data waktu perekaman, bias, gain, sun angle dan elevation diekstraksi dari metadata citra untuk nantinya diinputkan pada proses konversi digital number (DN) to radiance (persamaan 2) dan radiance to reflectance (persamaan 3). Proses ini dilakukan baik terhadap data citra pleiades utuh maupun citra subsetnya dengan nilai parameter pada Tabel 2.3 .

$$
L_{T O A}^{k}=\frac{X^{k}}{\alpha_{k}}+\beta_{k}
$$

dan :

$$
\rho_{T O A}^{k}=\frac{\pi L_{T O A}^{k}}{E_{S}^{k} \cdot \cos \left(\theta_{S}\right) \cdot d / d_{0}}
$$

Sumber : (OTB Development Team², 2018)

Keterangan :

$\mathrm{L}=$ radiance

$\rho=$ reflektansi

$\theta_{\mathrm{s}}=$ sudut matahari perekaman

$\mathrm{X}=$ Nilai Piksel $\alpha=$ gain $\beta=$ bias $\mathrm{E}_{\mathrm{S}}=$ Iluminasi Matahari

$\mathrm{d}=$ jarak matahari saat $\mathrm{d}_{0}=$ jarak rerata matahari

Tabel 2.3. Parameter Spektral Sensor Pleiades

\begin{tabular}{lcccc}
\hline \multirow{2}{*}{ Parameter } & \multicolumn{4}{c}{ Band } \\
\cline { 2 - 5 } & $\mathbf{r}$ & $\mathbf{g}$ & $\mathbf{b}$ & $\mathbf{p}$ \\
\hline Gain & 9,14 & 9,29 & 10,33 & 11,5 \\
bias $\left(W / \mathrm{m}^{2} /\right.$ steradians/micron) & 0 & 0 & 0 & 0 \\
Sun Ilumination $\left(W / \mathrm{m}^{2} /\right.$ micron $)$ & 1915 & 1830 & 1594 & 1548 \\
Sun angle & \multicolumn{3}{c}{$43,965980685^{\circ}$} \\
Sun Elevation & \multicolumn{4}{c}{$185,973072911^{\circ}$} \\
Azimuth angle & \multicolumn{4}{c}{$8,645180641^{\circ}$} \\
Viewing angle & \multicolumn{3}{c}{} \\
\hline
\end{tabular}

Sumber : Data Citra Pleiades 2014 
Fusi citra yang pada dasarnya adalah proses penggabungan antara band MS dengan band $\mathrm{P}$ dilakukan untuk mendapatkan citra pleiades multispektral dengan resolusi pankromatik. Pada penelitian yang menggunakan OTB ini, proses fusi citra dibagi menjadi tahap superimpose dan tahap bundle to perfect sensor yang hasilnya ditunjukkan pada Gambar 2.3.

Tahap superimpose berfungsi untuk meresampling band MS dari resolusi 2 meter menjadi 0.5 meter sebelum fusi dilakukan. Pada tahap ini dipilih metoda interpolasi konvolusi kubik untuk menghasilkan gradasi nilai piksel yang dengan baik pada resolusi lebih tinggi. Kemudian pada tahap bundle to perfect sensor, dilakukan proses kalkulasi nilai piksel antara citra hasil superimpose dengan citra pankromatik sebagaimana ditunjukkan oleh (persamaan 4).

$$
P M S_{(i, j)}=\frac{P_{(i, j)}}{P_{(s m o o t h)}} x M S_{(i, j)}
$$

Sumber : OTB Development Team², 2018

Keterangan :

PMS = piksel fusi $\quad \mathrm{P}=$ piksel band

pankromatik

$\mathrm{P}_{(\text {smooth })}=$ rata-rata pankromatik $\mathrm{MS}=$ piksel band multispektral

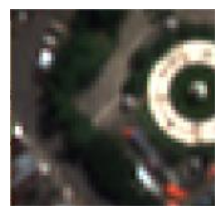

(a)

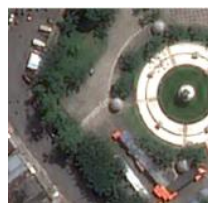

(b)
Gambar 2.3. Proses Fusi Citra Pleiades

(a) Sebelum, (b) Sesudah Fusi

Proses sensor model refinement yang dilakukan dalam penelitian ini berupa perbaikan model sensor model. Karena OTB tidak memiliki fitur digitasi onscreen, maka penempatan titik GCP pada citra ini dilakukan dengan aplikasi ESA SNAP 6 untuk mencari koordinat piksel dari titik GCP. Pada aplikasi tersebut diperoleh 10 titik kontrol tanah yang koordinat pikselnya dapat diamati pada Gambar 2.4.

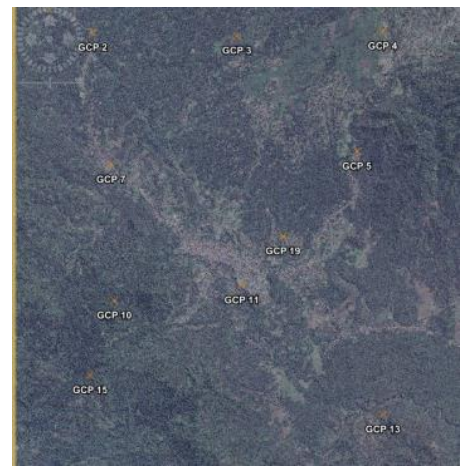

Gambar 2.4. Sebaran GCP Pada Subset Citra Pleiades
Proses refine sensor model membutuhkan data sensor model berformat OSSIM berupa file *.geom, data koordinat piksel dan koordinat lapangan titik GCP dalam bentuk file teks, serta data model permukaan berupa DEM. Dengan data tersebut, dilakukan transformasi affine berbasis least square secara iteratif sebagaimana ditunjukkan pada (Persamaan 5). Proses ini tidak secara langsung menghasilkan citra namun hanya menghasilkan file .geom.

$$
\begin{aligned}
& \mathrm{r}_{\text {refined }}=\mathrm{a}_{0}+\mathrm{a}_{1} \cdot \operatorname{rpf}_{\mathrm{r}}(\lambda, \varphi, \mathrm{h})+\mathrm{a}_{2} \cdot \operatorname{rpf}_{\mathrm{c}}(\lambda, \varphi, \mathrm{h}) \\
& \text { Crefined }=\mathrm{b}_{0}+\mathrm{b}_{1} \cdot \operatorname{rpf}_{\mathrm{c}}(\lambda, \varphi, \mathrm{h})+\mathrm{b}_{2} \cdot \operatorname{rpf}_{\mathrm{r}}(\lambda, \varphi, \mathrm{h})
\end{aligned}
$$

Sumber : Hoja, dkk., 2008

\section{Keterangan :}

$\operatorname{rpf}(\lambda, \varphi, \mathrm{h})$ : rational poynomial function asli

$$
\begin{array}{ll}
\mathrm{a}, \mathrm{b} & : \text { konstanta parameter transformasi affine } \\
\mathrm{r}, \mathrm{c} \text { refined } & \text { : koordinat piksel terkoreksi }
\end{array}
$$

Pada penelitian ini, ortorektifikasi terhadap citra pleiades dilakukan dengan mengganti file .geom dari citra hasil fusi dengan file .geom hasil refine sensor model, untuk kemudian diproses dengan ortorektifikasi sistematik pada perangkat lunak OTB. Selanjutnya, ketelitian geometrik citra satelit dari proses ortorektifikasi baik itu antar citra maupun pada citra utuh dan subsetnya dievaluasi dengan titik sekutu dan yang sebarannya nampak pada Gambar 2.5 dan Independent Check Point (ICP) yang sebarannya nampak pada Gambar 2.6. Penentuannya penempatan titik-titik tersebut dilakukan pada aplikasi QGIS.

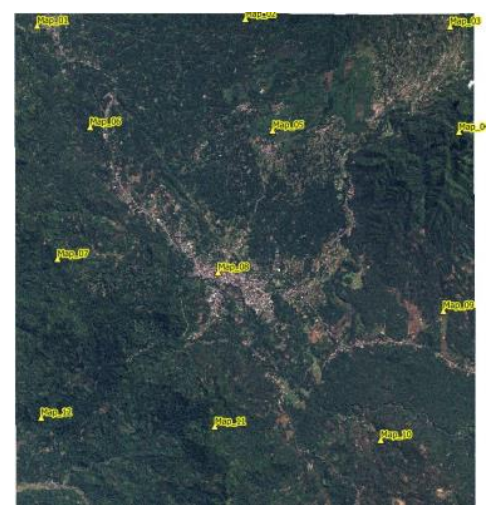

Gambar 2.5. Sebaran titik Sekutu Antar Citra

Nilai ketelitian dari selisih antara citra dan selisih koordinat posisi ICP pada citra dengan posisi di lapangan dalam nilai RMS sumbu $\mathrm{x}, \mathrm{y}$, sebagaimana pada persamaan (7) dan gabungannya berupa RMS bidang horisontal. Nilai tersebut diperhitungkan baik pada citra Pleiades utuh, maupun pada citra subsetnya sebagaimana nampak pada Persamaan (6). 


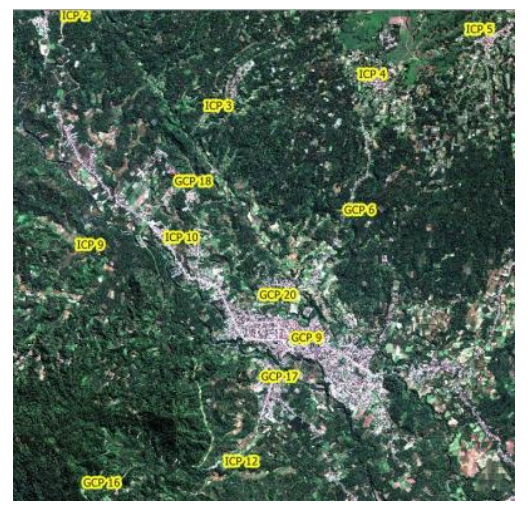

Gambar 2.6. Sebaran ICP Pada Subset Citra Pleiades

$$
R M S_{e}=\sqrt{\frac{R M S_{x}^{2}+R M S_{y}^{2}}{n}}
$$

Dimana :

$$
R M S_{(x, y)}=\sqrt{\frac{\sum\left(\Delta_{x}^{2}+\Delta_{y}^{2}\right)}{n}}
$$

Sumber : ASPRS., 2014 (dengan modifikasi)

Keterangan :

RMS $\quad$ : RMS error

$\operatorname{RMS}_{(\mathrm{x}, \mathrm{y})}$ : RMS sumbu $\mathrm{x}$ atau RMS sumbu y

$\Delta(\mathrm{x}, \mathrm{y}) \quad$ : Selisih koordinat citra dan koordinat lapangan

\section{Hasil dan Pembahasan}

Hasil-hasil dari penelitian mengenai ketelitian geometrik citra satelit Pleiades ini terdiri dari beberapa pembahasan, yang pertama mengenai kondisi pengolahan data dengan perangkat lunak OTB yang bersifat open source, dimana dilakukan peninjauan terhadap kondisi ukuran data, CPU load, dan waktu pemrosesan pada perangkat baik lunak maupun perangkat keras sebagai kontribusi dalam hal performa bagi pengembangan aplikasi OTB.

Yang kedua adalah hasil proses penempatan titik GCP dan ICP pada citra Pleiades dan, yang ketiga mengenai hasil proses sensor model refinement, dan yang terakhir adalah analisis mengenai ketelitian geometrik citra hasil Ortorektifikasi baik itu citra utuh maupun subsetnya.

\subsection{Pengolahan Data Dengan OTB}

Tahapan pengolahan citra yang dilakukan oleh OTB pada bervariasi tergantung pada ukuran data input serta kompleksitas proses matematis yang dilakukan pada tiap tahap. Tabel 3.1 Menunjukkan ukuran data setiap proses yang menjadi tahapan dari pengolahan data dengan OTB. Nampak bahwa secara umum, proses pada citra utuh memiliki ukuran data yang jauh lebih besar, dengan selisih hingga 39,28 GB sedangkan pyramidnya 13,15 GB.
Tabel 3.1. Ukuran Citra Utuh dan Subset pada tiap tahap

\begin{tabular}{lcccc}
\hline \multirow{2}{*}{ Data } & \multicolumn{4}{c}{ Ukuran File Citra (GB) } \\
\cline { 2 - 5 } & subset & Pyramid & Utuh & Pyramid \\
\hline MS & 0,38 & 0,10 & 1,03 & 0,32 \\
P & 2,03 & 0,67 & 5,46 & 1,82 \\
MS (Terkalibrasi) & 0,38 & 0,10 & 1,03 & 0,32 \\
P (Terkalibrasi) & 2,03 & 0,67 & 5,46 & 1,82 \\
MS (imposed) & 6,08 & 2,03 & 16,41 & 5,47 \\
Fusi (PMS) & 6,08 & 2,03 & 16,41 & 5,47 \\
Ortorektifikasi & 6,13 & 2,03 & 16,58 & 5,55 \\
\hline Total & 23,10 & 7,63 & 62,38 & 20,78 \\
\hline
\end{tabular}

Dalam eksekusi pengolahan Citra, OTB telah mampu memanfaatkan spesifikasi perangkat yang digunakan dimana seluruh inti yang dinyatakan dalam jumlah CPU dipakai untuk melakukan proses pengolahan citra sebagaimana ditunjukkan pada Gambar 8. Sehingga pada sistem yang memiliki inti lebih banyak, pengolahan citra dengan OTB akan lebih optimal.

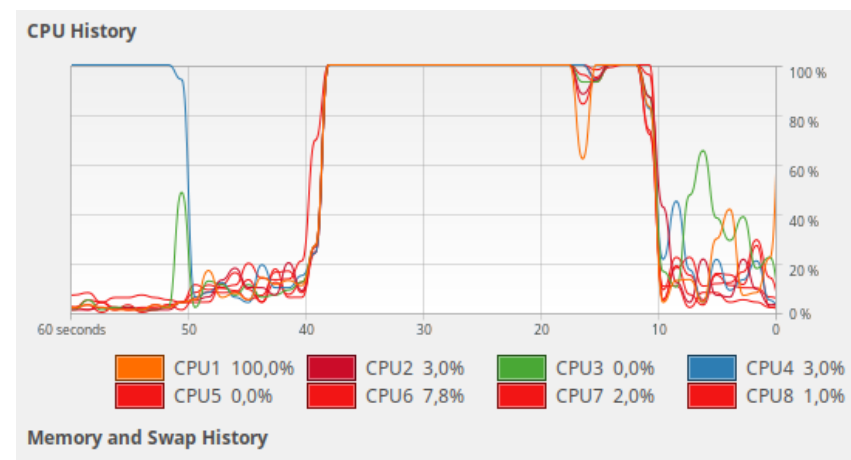

Gambar 3.1. Rekaman Proses CPU dari Ortorektifikasi Pada Linux Mint 19

Nampak pada Gambar 3.1 bahwa pada detik 10 hingga detik 40 penggunaan seluruh cpu mencapai $100 \%$. Selain itu, secara umum, proses pengolahan citra utuh lebih lama dibanding dengan subsetnya sebagaimana ditunjukkan pada Tabel 3.2. Dengan selisih total hingga 3.492,568 detik.

Tabel 3.2. Waktu pengolahan Citra

\begin{tabular}{lrr}
\hline \multicolumn{2}{c}{ Data } & \multicolumn{2}{c}{ Waktu (detik) } \\
\cline { 2 - 3 } & \multicolumn{1}{c}{ subset } & Utuh \\
\hline MS & 40,989 & 89,591 \\
P & 253,422 & 826,778 \\
MS (Terkalibrasi) & 39,990 & 105,475 \\
P (Terkalibrasi) & 248,830 & 663,994 \\
MS (imposed) & 1329,390 & 1580,110 \\
Fusi (PMS) & 1528,730 & 2211,160 \\
Ortorektifikasi & 880,599 & 2337,410 \\
\hline Total & 4321,950 & 7814,518 \\
\hline
\end{tabular}




\subsection{Tahap penempatan titik GCP dan ICP}

Perangkat lunak OTB tidak memiliki fitur digitasi onscreen sehingga perangkat lunak ESA SNAP digunakan untuk menempatkan titik-titik GCP pada citra. Dalam hal ini karena data georeferensi dalam struktur OSSIM tidak dapat dibaca oleh ESA SNAP, maka nilai koordinat GCP yang diperoleh hanya berupa koordinat piksel (Tabel 3.3).

Tabel 3.3. Koordinat GCP Piksel Subset

\begin{tabular}{lrrrr}
\hline \multirow{2}{*}{ Nama } & \multicolumn{1}{c}{ Citra Subset } & \multicolumn{1}{c}{ Citra Utuh } \\
\cline { 2 - 5 } & \multicolumn{1}{c}{ X } & \multicolumn{1}{c}{ X } & \multicolumn{1}{c}{ Y } \\
\hline GCP 2 & 6857,5 & 4671,5 & 7719,5 & 30907,5 \\
GCP 13 & 24802,5 & 28254,5 & 25664,5 & 54490,5 \\
GCP 3 & 15774,5 & 4866,5 & 16637,5 & 31101,5 \\
GCP 4 & 24790,5 & 4584,5 & 25652,5 & 30820,5 \\
GCP 7 & 7995,5 & 12828,5 & 8857,5 & 39064,5 \\
GCP 5 & 23191,5 & 12008,5 & 24053,5 & 38244,5 \\
GCP 19 & 18627,5 & 17243,5 & 19488,5 & 43480,5 \\
GCP 11 & 16078,5 & 20274,5 & 16940,5 & 46510,5 \\
GCP 10 & 8200,5 & 21215,5 & 9062,5 & 47451,5 \\
GCP 15 & 6705,5 & 25829,5 & 7567,5 & 52065,5 \\
\hline
\end{tabular}

Penempatan titik pada citra yang diperoleh memerlukan interpretasi posisi titik yang baik. Untuk setiap titik yang ditempatkan, diperlukan perentangan kontras yang menyesuaikan variasi nilai piksel pada posisi penempatannya sebagaimana ditunjukkan pada Gambar 3.2. nampak bahwa nilai piksel citra asli (a) yang direntangkan dengan kontras lokal (b) memungkinkan interpretasi yang lebih baik dibanding perentangan global pada keseluruhan citra (c).

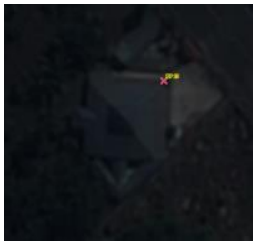

a. Citra Asli

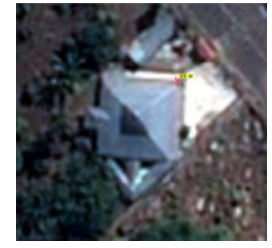

b.Perentangan Lokal

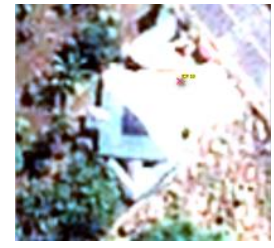

c. Perentangan global
Gambar 3.2. Perentangan Kontras Citra

\subsection{Analisis hasil Sensor Model Refinement}

Proses Sensor Model Refinement mengubah nilai dari paramater fungsi polinomial sensor yang terdapat pada file *.geom dari citra. Untuk dapat menghasilkan keluaran yang baik dari proses refinement terhadap subset citra Pleiades sebagaimana ditunjukkan Tabel 3.4, diperlukan koordinat piksel citra asli, dengan demikian, OTB memproses citra subset sebagai ROI dari citra utuh.

Nilai ketelitian yang diperoleh merupakan nilai final accuracy dari proses transformasi affine dari koordinat titik GCP pada citra menjadi koordinat titik GCP sebenarnya di lapangan hasil pengukuran GPS.

Tabel 3.4. Hasil Perbaikan Sensor Model

\begin{tabular}{lrr}
\hline \multirow{2}{*}{ Ketelitian } & \multicolumn{2}{c}{ Nilai (m) } \\
\cline { 2 - 3 } & Citra subset & Citra Utuh \\
\hline Overall RMSe & 1,54952 & 1,21727
\end{tabular}

\begin{tabular}{lrr} 
Rerata error X & 0,0900279 & 0,0253299 \\
Deviasi standard X & 1,29082 & 0,966643 \\
RMS error X & 1,29396 & 0,966975 \\
Rerata error Y & 0,113692 & 0,102363 \\
Deviasi standard Y & 0,844851 & 0,732272 \\
RMS error Y & 0,852466 & 0,739392 \\
\hline
\end{tabular}

3.4. Kesesuaian Antara Citra Utuh dan Subsetnya.

Nilai kesesuaian data yang diperoleh dari pembandingan antar citra dimana posisi citra subset dibandingkan dengan posisi citra utuh membutuhkan titik sekutu yang dipilih tersebar dengan posisi tersebar pada citra dengan hasil ditunjukkan pada tabel 3.5.

Tabel 3.5. Hasil Pengujian Ketelitian Relatif Citra

\begin{tabular}{lc}
\hline Ketelitian & Nilai $\mathbf{( m )}$ \\
\hline RMS error X & 0,227 \\
RMS error Y & 0,366 \\
Overall RMSe & 0,431 \\
\hline
\end{tabular}

\subsection{Ketelitian Geometrik Citra Hasil Ortorektifikasi}

Proses pengolahan citra dalam bentuk ortorektifikasi yang dilakukan sebagai proses akhir memanfaatkan fitur ortorektifikasi sistematik dari aplikasi OTB. Namun karena model sensor yang digunakan adalah model sensor yang telah diperbaiki, maka pada Tabel 3.6 diperoleh hasil lebih baik daripada ketelitian ortorektifiksi sistematik pada umumnya sebagaimana diperoleh pada penelitian Widyningrum, dkk., (2017), yaitu sebesar kurang lebih 3 meter.

Tabel 3.6. Hasil Pengujian Ketelitian Hasil Ortorektifikasi

\begin{tabular}{lcc}
\hline \multirow{2}{*}{ Ketelitian } & \multicolumn{2}{c}{ Nilai (m) } \\
\cline { 2 - 3 } & Citra subset & Citra Utuh \\
\hline RMS error X & 0,560 & 0,380 \\
RMS error Y & 0,501 & 0,172 \\
Overall RMSe & 0,751 & 0,416 \\
\hline
\end{tabular}

\section{Kesimpulan}

Perangkat lunak OTB yang bersifat open source dapat digunakan untuk melakukan ortorektifikasi dengan stabil kendati memiliki kelemahan tidak adanya fitur digitasi onscreen sehingga aplikasi lain perlu digunakan untuk mendapatkan data koordinat piksel citra maupun koordinat geometrik citra pada proses pengujian ketelitian hasil ortorektifikasi.

Proses pengolahan citra tanpa perentangan kontras diperlukan untuk menjaga variasi nilai piksel citra asli. Jika kontras citra direntangkan secara permanen secara global, maka proses perentangan lokal tidak dapat mengubah tampilan citra karena detail variasi lokal dari nilai piksel citra telah hilang.

Proses pengolahan citra subset memiliki ukuran data luaran yang lebih kecil sebagaimana ditunjukkan tabel 4 serta waktu pengolahan yang lebih singkat sebagaimana 
ditunjukkan t Penambahan data pyramid secara otomatis yang berfungsi mempercepat tampilan citra oleh berbagai aplikasi pengolah citra juga menambah besar ukuran data secara keseluruhan. Citra subset memiliki total 30,73 GB, sedangkan citra utuh pada prosesnya menghasilkan total 83,15 GB. Oleh sebab itu, sumber data yang telah terfusi disamping data yang berupa subset sangat mengurangi kapasitas penyimpanan yang dibutuhkan

Akurasi citra yang yang terdiri dari hasil pembandingan relatif antar citra, akurasi sensor model, dan akurasi terhadap koordinat tanah dimana diperoleh ketelitian terhadap ICP sebesar 0,416 meter sehingga terdapat perbedaan antara akurasi citra utuh dan citra subsetnya masing-masing 0,416 meter dan 0,751 meter. perbedaan tersebut diantaranya disebabkan oleh adanya perbedaan posisi penempatan titik GCP maupun ICP pada citra satelit.

\section{Pernyataan Konflik Kepentingan}

Penulis menyatakan tidak ada konflik kepentingan dalam artikel ini (The authors declare no competing interest).

\section{Referensi}

ASPRS, (2014). "ASPRS Positional Accuracy Standards for Digital Geospatial Data" Photogrammetric Engineering \& Remote Sensing, 81, pp. A1-A26

Hoja, D., Schneider, M., Müller, R., Lehner, M., Reinartz, P., (2008). Comparison of orthorectification methods suitable for rapid mapping using direct georeferencing and RPC for optical satellite data, Beijing ISPRSarchives XXXVII B1 pp 1617-28

Mateo C. M. R., Yamazaki D., Kim H., Champathong A., Vaze J., and Oki T., (2017). Impacts of spatial resolution and representation of flow connectivity on large-scale simulation of floods Hydrology \&. Earth System Science 21 5143-5163

https://doi.org/10.5194/hess-21-5143-2017

Müller R., Krauß T., Schneider M., and Reinartz P. (2011). Automated Georeferencing of Optical Satellite Data with Integrated Sensor Model Improvement, Photogrammetric Engineering \& Remote Sensing 781 61-74

OTB Development Team ${ }^{1}$, (2018) The ORFEO ToolBox Software Guide, Updated for 0TB-6.6.0, CNES https://www.orfeo-toolbox.org/SoftwareGuide Diakses pada 5 September 2018

OTB Development Team², (2018) The ORFEO CookBook Documentation OTB-6.6.0 Version, CNES

https://www.orfeotoolbox.org/packages/ OTBCookBook.pdf

Diakses pada 5 September 2018

Widyaningrum E., Fajari M., and Octariady J. (2016) Accuracy comparison of VHR systematic-ortho satellite imageries against VHR orthorectified imageries using GCP, Prague ISPRSarchives XLI B4 305-309 